\title{
PENGARUH ASAP CAIR TEMPURUNG KELAPA TERHADAP $P$. palmivora PENYEBAB PENYAKIT BUSUK BUAH PADA KAKAO
}

\author{
THE EFFECT OF COCONUT SHELL VINEGAR (LIQUID SMOKE ON POD ROT OF \\ CACAO DISEASE (P. palmivora)
}

Yunita, Iman Suswanto dan Sarbino

\begin{abstract}
Program Studi Agroteknologi Fakultas Pertanian Universitas Tanjungpura
\end{abstract}
Jln. Prof. Dr. Hadari Nawawi, Pontianak, 78124, Indonesia.

\begin{abstract}
ABSTRAK
Penyakit busuk buah yang disebabkan oleh P.palmivora merupakan salah satu penyakit penting pada tanaman kakao kerena menyebabkan kerugian cukup besar pada hasil panen. Salah satu cara pengendalian busuk buah menggunakan asap cair tempurung kelapa. Penelitian ini bertujuan memperoleh konsentrasi asap cair untuk menekan aktivitas P.pamivora. Penelitian berlangsung selama tiga bulan di Laboratorium Penyakit Tanaman Fakultas Pertanian Universitas Tanjungpura. Metode yang digunakan adalah Rancangan Acak Lengkap (RAL) dengan 6 perlakuan $0 \%, 5 \%, 10 \%, 20 \%, 40 \%$ dan fungisida berbahan aktif mancozeb $80 \%$ di ulang 3 kali. Parameter yang diamati adalah jumlah bercak dan panjang bercak, pengamatan dimulai pada hari kelima setelah inkubasi. Hasil penelitian menunjukan bahwa pengendalian penyakit busuk buah menggunakan cuka kayu efektif pada konsentrasi $5 \%$ dan $10 \%$ yang mampu menghambat aktivitas P.palmivora.
\end{abstract}

Kata Kunci: Buah kakao, asap cair tempurung kelapa, P.palmivora.

\section{ABSTRACT}

Cocoa pod rot disease is one of the important diseases on cocoa crop because they cause substantial losses in crop yields. One method to control spoilage of pod using vinegar (Liquid Smoke) coconut shell. This research aims to obtain a concentration of Vinegar (Liquid Smoke) to suppress the activity of P. pamivora. The study lasted for three months in the laboratory of plant disease Faculty of Agriculture University of Tanjungpura. The method used was Complete Random Design (CRD) with 6 treatment 0\%, 5\%, 10\%, 20\%, 40\% and fungicides mancozeb 80\% active material based on 3 times replications. The observed parameters is the number of patches and spots, long observations began on the fifth day after incubation. The research results showed that rotten pod disease control using Wood Vinegar is effective at concentrations of 5\% and $10 \%$ are able to inhibit the activity of P. palmivora.

Key words: Cocoa pod, vinegar (asap cair), coconut shell, P. palmivora.

\section{PENDAHULUAN}

Penyakit busuk buah merupakan salah satu penyakit penting tanaman kakao dan sampai saat ini masih menjadi ancaman serius didaerah penghasil kakao. Kerugian yang ditimbulkan akan lebih tinggi bila penyakit ini terjadi di lokasi-lokasi yang endemis, terutama di daerah relatif basah pada musim hujan (McMahon dan Purwantara, 2004 dalam Nur Aeny dkk
2011). P. palmivora merupakan salah satu patogen utama penyebab penyakit busuk buah tanaman kakao pada berbagai daerah sentra produksi di Indonesia, berakibat pada penurunan produksi secara drastis dengan kerugian berkisar 32,6-99\% (Sukamto, 2008 dalam Umrah dkk, 2009).

Berbagai usaha dilakukan untuk mengendalikan penyakit yang disebabkan oleh patogen, diantaranya menggunakan 
pestisida anorganik. Pestisida anorganik dalam penerapannya telah terbukti dapat menekan kerugian atau kerusakan, sehingga sampai saat ini peran pestisida tidak dapat dilepas dalam pencapaian target produksi. Namun disisi lain, pestisida anorganik berdampak negatif. Ini disebabkan pestisida anorganik biasanya disintesa dari bahan yang tidak terbarukan ( seperti batu bara dan minyak bumi) sehingga umumnya beracun dan berdampak negative terhadap lingkungan (Aisyah, 2012).

Mengingat kemungkinan efek samping yang ditimbulkan, maka perlu dikembangkan pestisida yang bersifat mudah terdegradasi secara alami, bersifat toksik terhadap mikroorganisme sasaran, tetapi tidak bersifat toksik terhadap manusia dan binatang disekitarnya, tidak mencemari lingkungan, dan tidak berbahaya bagi kesehatan manusia ( Soetarno, 1994 dalam Aisyah, 2012). Salah satu alternatif pestisida untuk mengatasi masalah tersebut adalah dengan mengembangkan bahan biokatif berasal dari tumbuhan. Diantara bahan bioaktif adalah asap cair tempurung kelapa yang diperoleh dari hasil kondensasi fraksi uap atau gas yang terbentuk selama proses pengarangan (destilasi kering) kayu atau bahan berserat berlignin selulosa lain.

\section{BAHAN DAN METODE}

Penelitian ini dilaksanakan di Laboratorium Penyakit Tanaman Fakultas Pertanian Universitas Tanjungpura. Pengambilan Buah Kakao bertempat di Desa Pematang Tujuh Kecamatan. Rasau Jaya dan isolat P.palmivora diperoleh dari Praktikum di Laboratorium APH BPTP Pontianak. Cuka Kayu Tempurung Kelapa didapat dari D3 Perkebunan Universitas Tanjungpura. Penelitian ini dilaksanakan dari bulan Agustus sampai Oktober 2015. Penelitian ini menggunakan Rancangan Acak Lengkap (RAL) yang terdiri atas 6 perlakuan dengan 3 ulangan. Perlakuan asap cair dengan konsentrasi yaitu 0\%, 5\%, 10\%, 20\%, 40\% dan fungisida berbahan aktif Mancozeb $80 \%$ $1,5-2 \mathrm{~g} / \mathrm{l}$.

\section{Alat dan Bahan Penelitian.}

Alat yang digunakan dalam penelitian yaitu: Laminar air flow, kamera, cawan petridish, erlenmeyer, autoklaf, objek glass, mikroskop, pisau cutter, jarum ose, kertas label, meteran, alat tulis, wadah plastik (mika), sprayer, beker gelas. Bahan yang digunakan antara lain: buah kakao, asap cair tempurung kelapa, aquades, kapas, surfaktan, biakan murni P.palmivora, media PDA (Potato Dextrose Agar), media WA (Water Agar), alkohol 70\%, antibotik, spirtus, tissue, kapas.

\section{Pelaksanaan Penelitian.}

Terlebih dahulu alat-alat yang akan digunakan disterilisasi menggunakan autoclave. Pembuatan isolat P.palmivora dilakukan dengan cara membersihkan terlebih dahulu permukaan buah secara keseluruhan, menggunakan alkohol. Jaringan buah yang terinfeksi dan berbatasan dengan jaringan sehat dipotong dengan ukuran $1 \mathrm{~cm} \mathrm{x}$ $1 \mathrm{~cm}$. Selanjutnya ditanam pada media WA, diinkubasi selama 5 hari, setelah tumbuh miselium berwarna putih pada media WA dilakukan pemurnian pada media PDA. Dilanjutnya dengan identifikasi menggunakan mikroskop dan diperbanyak 15 petri. Isolat $P$. palmivora yang telah diperbanyak menggunakan media PDA ditambahkan $10 \mathrm{ml}$ aquades steril (untuk 1 petri) kemudian dihomogenkan, setelah itu suspensi dimasukan kedalam sprayer (Azis, 2013).

Pelarut disiapkan terlebih dahulu untuk pengenceran, dengan mencampurkan $3 \mathrm{ml}$ surfaktan ke dalam $1.997 \mathrm{ml}$ aquades menggunakan beker gelas sehingga volume menjadi 2 liter larutan induk. Persiapan larutan asap cair dilakukan dengan membuat pengenceran sesuai konsentrasi yang telah ditentukan. 
Buah kakao terlebih dahulu dicuci, setelah kering disterilisasi menggunakan alkohol dan diletakkan pada wadah mika, kemudian dilukai menggunakan jarum ose pada bagian ujung, tengah, dan pangkal dengan masing-masing 10 titik pelukaan. Setiap wadah berisi tiga buah kakao yang masing-masing sama bentuknya. Buah yang disiapkan kemudian disemprot asap cair tempurung kelapa sesuai perlakuan. Buah diinkubasi selama 1 hari agar cuka kayu menempel. Buah kakao diinkubasi dan diamati perkembangan bercak busuk buahnya sampai hari ke 11. Pada pengamatan hari ke 11 panjang bercak busuk buah sudah mencapai panjang maksimal. Variabel pengamatan yang pertama adalah panjang bercak busuk buah, Pengukuran panjang bercak dilakukan hari ke 5 setelah inkubasi. Pada hari ke 5 sudah terlihat gejala, panjang bercak diukur dengan tali meteran dengan satuan $\mathrm{cm}$. Kedua jumlah bercak busuk buah, Penghitungan jumlah bercak dilakukan hari ke 5 setelah inkubasi. Masing-masing buah diamati jumlah bercaknya. Data hasil pengamatan berupa panjang bercak busuk dan jumlah bercak ditransformasi Akar Kuadrat $X=\sqrt{(X+0.5)}$, Analisis statistik menggunakan program SAS.

\section{HASIL DAN PEMBAHASAN}

\section{Pengaruh Asap Cair terhadap Perkembangan Penyakit}

\section{Jumlah Bercak}

Hasil analisis menunjukan bahwa jumlah busuk yang terbentuk akibat infeksi P.palmivora pada beberapa konsentrasi asap cair berbeda secara nyata seperti pada Tabel 1. Pada konsentrasi 5\%-10\% mampu menekan terbentuknya jumlah busuk buah. Sementara penggunaan lebih dari 20\% dapat menyebabkan fitotoksisitas.

Penggunaan asap cair mampu menekan jumlah bercak, hal ini disebabkan asap cair tempurung kelapa mengandung senyawa aktif yang berperan sebagai antimikroba (Girrad, 1992 dalam Pangestu, 2013). Senyawa aktif yang terkandung dalam asap cair tempurung kelapa yang digunakan dalam penelitian adalah fenol sebesar 17,398 mg/l.

Tabel 1. Pengaruh Asap Cair Tempurung Kelapa terhadap Panjang Bercak dan Jumlah Bercak Busuk Buah Kakao.

\begin{tabular}{lrrrrr}
\hline \multirow{2}{*}{ Fungsida } & \multicolumn{5}{c}{ Perkembangan Penyakit } \\
\cline { 2 - 6 } & \multicolumn{4}{c}{ Rerata Panjang Bercak } & Rerata Jumlah Bercak \\
\hline Kontrol & 5,14 & a & 0,70 & a \\
Mancozeb & 0,95 & b & 0,25 & $\mathrm{~b}$ \\
Asap Cair 5\% & 1,31 & $\mathrm{~b}$ & 0,26 & $\mathrm{~b}$ \\
Asap Cair 10\% & 1,66 & $\mathrm{~b}$ & 0,40 & $\mathrm{ab}$ \\
Asap Cair 20\% & 6,00 & $\mathrm{a}$ & 0,66 & $\mathrm{a}$ \\
\hline
\end{tabular}

Keterangan: Angka yang diikuti huruf yang sama dalam satu kolom menunjukkan tidak berbeda nyata menurut uji LSD 0.05 . (-) Terjadi fitotoksisitas sehingga buah tidak dapat diamati. Konsentrasi $40 \%$ terjadi fitotoksisitas sehingga buah tidak dapat diamati.

Tabel 1. Menjelaskan pada perlakuan konsentrasi $40 \%$ terjadi fitotoksisitas, hal ini karena kandungan senyawa fenol pada asap cair meracuni jaringan buah kakao, yang dapat memperlemah ketahanan buah sehingga infeksi lebih mudah terjadi. (Sriwati, 2012), ketahanan suatu tanaman dipengaruhi dari jenis varietas tanaman, umur tanaman serta virulensi patogen yang juga dipengaruhi oleh jenis atau ras patogen. P.palmivora termasuk soprofit fakultatif yaitu jamur yang bersifat parasit jika mendapatkan inang yang sesuai, tetapi bersifat saprofit jika mendapatkan inang yang 
cocok. Jadi P.palmivora bisa hidup pada jaringan buah yang lemah akibat adanya aplikasi asap cair tempurung kelapa pada konsentrasi diatas $20 \%$, yang mengakibatkan jumlah bercak lebih banyak.

\section{Panjang Bercak}

Hasil analisis Tabel 1. menunjukan bahwa penggunaan beberapa konsentrasi asap cair nyata menekan perkembangan penyakit. Sehingga asap cair dengan rentang konsentrasi 5\%-10\% mampu menekan perkembangan penyakit. Pada konsentrasi cuka kayu lebih dari 20\% dapat menekan perkembangan penyakit tetapi dapat pula menimbulkan dampak keracunan pada buah kakao. Hal tersebut menunjukan kandungan fenol yang terdapat pada asap cair dapat menghambat pertumbuhan P.palmivora. Penelitian Pangestu (2013) konsentrasi 0,1\% dapat menghambat pertumbuhan jamur P.palmivora sebesar $50 \%$ secara in vitro.

Kimura et al. (2002) dalam Priyamto (2012) asap cair tempurung kelapa mengandung senyawa fenol yang mampu menghambat pertumbuhan bakteri atau jamur sehingga dapat digunakan sebagai disinfektan. Daya racun fungisida yang berperan dalam menghambat pertumbuhan jamur didalam asap cair berasal dari komponen fenol dan asam. Efektifitas asap cair dalam pengendalian penyakit busuk buah kakao dapat dilihat dari penambahan panjang bercak busuk buah, jika panjang bercak busuk buah sedikit selama pengamatan, maka konsentrasi yang digunakan efektif dalam menekan pertumbuhan jamur.

Pada taraf konsentrasi 5\% dan $10 \% P$. palmivora menggalami penghambatan pertumbuhan, hal tersebut menunjukan bahwa $P$. palmivora terhambat pertumbuhannya sehingga kecepatan pertumbuhan lebih lambat jika dibandingkan dengan konsentrasi yang lain. Fungisida dapat bersifat fungistatik, yaitu bersifat tidak membunuh cendawan tetapi hanya menghambat pertumbuhan serta bersifat genestatik yang mencegah sporulasi.

Pengamatan adanya jumlah bercak dan panjang bercak dilakukan setelah gejala muncul pada hari ke 5 setelah inkubasi. Hasil penelitian menunjukan bahwa bercak coklat akibat infeksi patogen pada buah kakao muncul pada satu titik setiap buahnya. Bercak tersebut kemudian berkembang hingga buah menjadi busuk total. Pengamatan busuk buah kakao dilaksanakan selama 11 hari dimulai setelah infeksi P.palmivora. Dari data tersebut infeksi pertama terjadi pada perlakuan kontol dan 20\%. Pada Tabel 1. Menjelaskan bahwa penggunaan konsentrasi diatas 20\% menyebabkan kerusakan pada buah, seperti pada perlakuan konsentrasi $40 \%$, tidak dapat dilakukan pengamatan karena permukaan buah rusak (fitotoksisitas). Sehingga tidak dianjurkan penggunaan cuka kayu pada konsentrasi tersebut khususnya pada buah kakao. 


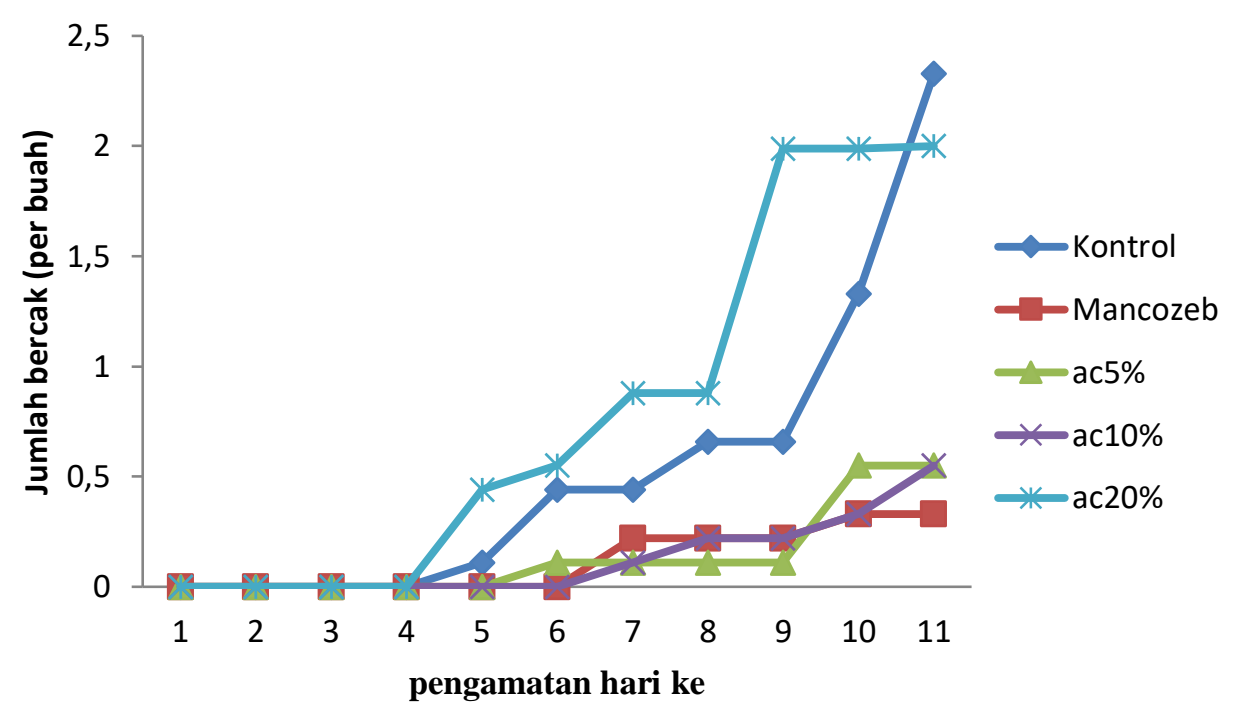

Gambar 1. Grafik Pertambahan Jumlah Bercak Pada Buah Kakao Akibat Infeksi P.palmivora 1 sampai 11 hari sesudah inokulasi.

\section{Perkembangan Penyakit Busuk Buah Setelah Pemberian Asap cair}

\section{Jumlah Bercak}

Pada gambar 1. Menunjukan bahwa bercak busuk buah muncul dimulai pada pengamatan hari ke 5 setelah inokulasi. Penambahan jumlah bercak terjadi pada pengamatan hari ke 6 . Grafik di atas menunjukan bahwa perlakuan asap cair 5\% dan $10 \%$ dapat menghambat penambahan jumlah bercak busuk buah, dibandingkan kontrol. Pada perlakuan 5\% dan $10 \%$ munculnya bercak dimulai pada hari ke 6 setelah inkubasi, hal ini dikarenakan senyawa aktif pada asap cair dapat menghambat lajunya $P$. palmivora dalam menginfeksi buah kakao.

Tarjot (1974) dalam Alhadi (2014)

buah kakao yang rentan terhadap $P$. palmivora jika selnya telah terinfeksi oleh patogen, maka perkembangan bercaknya akan lebih cepat sehingga pembusukan akan lebih cepat. Sedangkan kakao yang resisten, jika terinfeksi patogennya akan bertahan lama di dalam sel sebelum terjadinya nekrosis. Perpindahan patogen antar sel menjadi terhambat sehingga perkembangan bercak dan pembusukan akan melambat.

\section{Panjang Bercak}

Gambar 2. Menunjukan bahwa pertambahan panjang bercak pada masingmasing perlakuan memiliki perbedaan. Asap cair memiliki kemampuan menghambat masuk dan berkembangnya patogen di dalam jaringan buah, sehingga memiliki perkembangan panjang bercak yang lambat. 


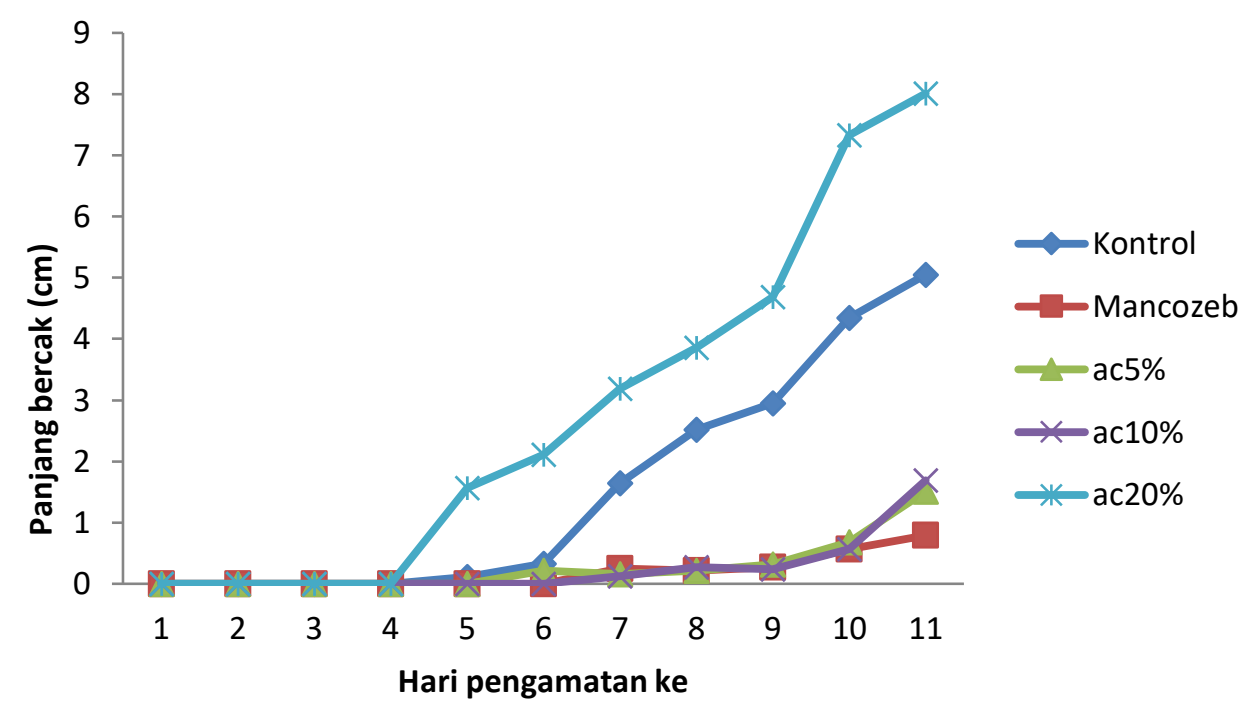

Gambar 2. Grafik Pertambahan Panjang Bercak Pada Buah Kakao Akibat Infeksi P.palmivora 1 sampai 11 hari sesudah inokulasi.

Perkembangan panjang bercak pada buah kakao berhubungan dengan ketahanan pasca penetrasi (Alhadi, 2014). Hal ini menunjukan adanya peranan mekanisme biokimiawi yang terjadi di dalam sel setelah terinfeksi oleh patogen. Gambar 2. Juga menunjukan bahwa perlakuan cuka kayu pada konsentrasi $5 \%$ dan $10 \%$ memiliki panjang bercak yang sama, akan tetapi masih belum bisa menyamai mancozeb. Pada perlakuan $20 \%$ terjadi penambahan panjang bercak yang sangat tinggi, ini diakibatkan terjadinya fitotoksisitas pada buah kakao setelah aplikasi asap cair. Dari grafik diatas asap cair dapat menghambat laju perkembangan panjang bercak, jika dibandingkan dengan kontrol sehingga aktifitas $P$. palmivora dapat dihambat oeleh senyawa aktif yang terkandung dalam cuka asap cair.

\section{SIMPULAN}

1. Asap cair tempurung kelapa dapat menghambat pertumbuhan $P$. palmivora pada kakao secara in vivo pada konsentrasi $5 \%$ dan $10 \%$.

2. Asap cair tempurung kelapa pada konsentrasi $5 \%$ dan $10 \%$ mampu menghambat panjang bercak dan jumlah bercak busuk buah kakao.

3. Penggunaan konsentrasi lebih dari $20 \%$ dapat menyebabkan fitotoksisitas pada buah kakao.

\section{DAFTAR PUSTAKA}

Aisyah, I., Nuryati, J., dan P. Gustan, 2012. Pemanfaatan Asap Cair Tempurung Kelapa Untuk Mengendalikan Cendawan Penyebab Penyakit Antraknosa dan Layu Fusarium pada Ketimun. Jurnal Penelitian Hasil Hutan, 31(2). 21-31.

Irawati, A., R. Ade dan SD. Vien, 2013. Pengendalian Penyakit Hawar Daun Phytophthora palmivora Pada Bibit Kakao dengan Tricoderma asperellum". Jurnal Fitopatologi Indonesia, 9(1):15-20.

Nur Aeny, T., J. Siti dan M. Tri., 2011. Potensi Antagonis Beberapa Isolat Trichoderma Terhadap Phytophthora palmivora, Penyebab Penyakit Busuk Buah Kakao. Seminar Nasional Sains dan Teknologi-IV, 34(2):521-533.

Pangestu E., 2013. Uji Penggunaan Asap Cair Tempurung Kelapa Dalam 
Pengendakian Phytophthora palmivora $s p$ Penyebab Penyakit Busuk Buah Kakao Secara In vitro. Skripsi. Fakultas Pertanian Universitas Tanjungpura. Tidak dipublikasi.

Priyamto, S., A.O, Hasan, Wahdina, dan D. Farah, 2012. Aplikasi Asap Cair Dari Kayu Leban (Vitex pubescens Vahl) Untuk Pengendalian Jamur Pada Benih Tusam (Pinus merkusii Jungh et de Vriese) Secara In Vitro. Skripsi. Fakultas Kehutanan Universitas Tanjungpura. Tidakk dipublikasi.

Rubiyo dan W. Amaria, 2013. Ketahanan Tanaman Kakao Terhadap Penyakit Busuk Buah (Phytophthora palmivora Butl.). Jurnal Perspektif, 12(1): 23-36.
Sriwati, R. Dan M. Rizky, 2012. Characteristic Symptoms Of Phytophthora palmivora On Cocoa Leaves. Natural, 12(2): 30-34.

Susanto, F.X., 1993. Tanaman Kakao Budidaya dan Pengolahan Hasil. Penerbit Kanisius. Yogyakarta. 87 hal.

Umrah., T. Anggraeni, R. Rachmi, I. Esyanti, I.N. Aryantha, 2009. Antagonisitas dan Efektivitas Trichoderma $s p$ Dalam Menekan Perkembangan Phytophthora palmivora Pada Buah Kakao. Jurnal Agroland, $\quad$ 16(1): $\quad 9-16$ 